\title{
Yığma Duvarların Mikro Seviye Modellemesinde Tuğlanın Basınç Dayanımı ve Kayma Gerilmesi İletim Katsayısının Nümerik Çözümler Üzerindeki Etkisinin İncelenmesi \\ Investigation of the Effect on Solutions of Compressive Strength and Shear Transfer Coefficient of Brick in Micro Modeling of Masonry Walls

\author{
Muhammet Karaton ${ }^{1 *} \oplus$, Kağan Çanakçı1 ${ }^{\circledR}$,
}

Fırat Üniversitesi, Mühendislik Fakültesi, İnşaat Mühendisliği Bölümü, Elazığ, 23119, Türkiye ${ }^{1}$

Sorumlu Yazar / Corresponding Author*: mkaraton@firat.edu.tr

Atıfssekli/How to cite: KARATON, M., CANAKÇı, K.(2020). Yığma Duvarların Mikro Seviye Modellemesininde Tuğlanın Basınç Dayanımı ve Kayma Gerilemesi İletim Katsayısının Nümerik Çözümleri Üzerindeki Etkisinin İncelenmesi. DEUFMD 22(65), 383-392.

Öz

Bu çalışmada, yığma duvarların mikro model ile analizinde 3 boyutlu sabit doğrultulu yayılı çatlak modelinin etkinliği incelenmiștir. Duvarın harç ve tuğla kısımlarının lineer olmayan davranıșını hesaplamak için William ve Warnke modelinin özel hali olan üç değişkenli beton modeli kullanılmıștır. Nümerik analizler için Ansys sonlu eleman programı içerisinde bulunan Solid65 beton elemanı seçilmiştir. Nümerik sonuçların karşılaştırılması amacıyla, JD4, JD6 ve JD7 Eindhoven duvarlarının deney sonuçlarından elde edilen taban kesme kuvveti-tepe yer değiştirme eğrisi ile olușan çatlak bölgeleri kullanılmıștır. Tuğlanın basınç dayanımının ve kayma gerilmesi iletim katsayısının çözümler üzerine olan etkisi incelenmiştir. Yığma yapıların mikro seviye statik itme analizlerinde kullanılması amacıyla tuğlanın basınç dayanımı için bir eşitlik ve kayma gerilmesi iletim katsayıları için değerler önerilmiştir.

Anahtar kelimeler: Eindhoven duvarları, Mikro Modelleme, Yayılı Çatlak Modeli, Tuğlanın basınç dayanımı ve Kayma gerilmesi iletim katsayısı

\section{Abstract}

In this study, the effectiveness of 3-dimensional fixed smeared crack model in the micro-model analysis of masonry walls is investigated. The three parameters concrete model which special case of William Warnke model, is used to calculate the nonlinear behavior of mortar and brick regions of this wall. For numerical analysis, Solid65 concrete element in Ansys finite element program is selected. For the comparison of the numerical results, the base shear force-top displacement curve and the cracking zones obtained from the experimental results of the Eindhoven walls JD4, JD6 and JD7 are used. An equation for compressive strength of the brick, and the values for shear stress transfer coefficients are recommended with purpose of using in micro level static push-over analyzes of masonry walls.

Keywords: Eindhoven Walls, Micro Modelling, Smeared Crack Model, Compressive Strength of Bricks and Shear Transfer Coefficient 


\section{Giriş}

Yı̆̆ma duvarlar, bina inşaatı için yüzyıllardır kullanılmış olup duvarı oluşturan malzemelerin birbirleriyle etkileșiminden dolayı kompleks davranışa sahiptirler. Nümerik olarak bu davranışın tam olarak elde edilememesine rağmen hala tercih edilen yapı elemanlarıdır. Yığma duvarlar bir beton veya çelik çerçevede dolgu malzemesi olarak veya tașıyıcı bir eleman olarak inșa edilmektedir. Dolgu malzemesi olarak kullanılan yığma duvarlar, binaların deprem sırasındaki davranışında olumlu katkı sağlamaktadır $[1,2]$. Bu nedenle bu yapı elemanlarının davranıșlarının doğru bir șekilde modellenmesi gerekmektedir.

Bu yapıların statik ve dinamik yükler altındaki davranışlarının belirlenmesinde farklı hesaplama metotları sunulmuștur. $\mathrm{Bu}$ hesaplama metotları mikro, basitleșitirilmiş mikro ve makro ölçekli analiz olarak üç grupta kategorize edilmiştir. Mikro ölçekli analizlerde, yığma duvarı oluşturan her bir malzemenin doğrusal olmayan davranıșı önemlidir. Aynı zamanda bu analizden elde edilen çatlak bölgesinin yörüngesi detaylı bir şekilde incelenmektedir. Basitleștirilmiș mikro ölçekli analizde, taş/tuğla boyutları harcın yarı kalınlığına kadar uzatılmaktadır. Böylece, sonlu elemanlar ağında harç ile taş/tuğla birimleri birlikte tanımlanmaktadır. Bu birimler arasında ise arayüzey elemanları tanımlanarak etkileşimleri sağlanmaktadır. Makro ölçekli modellemede ise taş/tuğla ve harç homojenleștirilmiş bir bölge olarak kabul edilmektedir. $\mathrm{Bu}$ alan için efektif malzeme özellikleri kullanılmaktadır. Mikro ölçekli yaklaşımdan elde edilen sonuçlar deney sonuçları ile karșılaștırıldığında kabul edilebilir seviyede sonuçlar vermektedir [3]. Bu modeller içerinde sabit doğrultulu yayılı çatlak modeli en yaygın olarak kullanılan modellerden biridir. $\mathrm{Bu}$ modelin yığma yapıların mikro model ile modellemesinde etkinliğinin incelenmesi önem arz etmektedir.

Chaimoon ve Attard [4], donatısız yığma duvarların, kesme ve basınç yüklemeleri altındaki doğrusal olmayan davranışını analiz etmek için bir model sundular ve bu modelin doğrulamasını yapmak amaciyla Vermeltfoort ve ark. [5]' nın yığma duvarlar için yaptıkları deney sonuçlarıyla karşılaştırmışlardır. Zucchini ve Lourenço [6], yığma duvarların, doğrusal olmayan analizi için bir mikro mekanik model geliştirdiler ve Vermeltfoort ile Raijmakers [7]' ın yı̆̆ma duvarlar için yaptıkları deney sonuçlarını kullanarak modelin doğrulamasını yaptılar. Adam ve ark. [8], yığma yapılar üzerinde yapılan bir dizi laboratuvar testleri için sonlu elemanlar yöntemi ile mikro mekanik modelleme yaptılar. Sonlu eleman modeline harç ve tuğla, katı eleman olarak bu iki ortamın ara yüzü ise ara yüzey elemanlarla modellenmiștir. Doğrusal olmayan nümerik analiz sonuçları ile deney sonuçları yük-yer değiştirme ve eğilme momenti-dönme tepkileri açısından karşılaştırılmıştır. Mohyeddin ve ark. [9], üç boyutlu ayrık sonlu elemanlar kullanarak yığma duvar ile doldurulmuş betonarme çerçevelerin analizlerini elde etmişlerdir. Çözümlerinde, ANSYS sonlu elemanlar programını kullanmışlardır. $\mathrm{Bu}$ modelin doğrulamasını yapmak amaciyla literatürde yer alan deneysel verileri kullanılmışlardır. Modelin düzlem içi ve düzlem dışı yükleme durumlarında, dolgu çerçeve üzerindeki etkisini doğru bir şekilde yansıttığını göstermişlerdir. Caporale ve ark. [10], farklı duvar örme biçimleri ve yükleme durumlarının kerpiç duvarlar üzerine etkisini incelemek için iki boyutlu mikro mekanik analiz yöntemini kullandılar. Deney sonuçları, basınç ve çekme yüklemeleri altındaki tuğla ve harcın farklı elastisite modüllerine sahip olduklarını göstermiştir. $\mathrm{Bu}$ durum mikro model oluşturulurken dikkate alınıp homojenleştirilmiş birim hücreler için asal gerilme düzlemlerindeki kritik eğriler oluşturulmuștur. Aynı zamanda, homojenleștirilmiș elastisite modülü ile yükleme açısı arasında bir ilişki elde edilmiştir. Petracca ve ark. [11] yığma duvarların analizi için yeni bir hasar mekaniği tabanlı sürekli mikro model sundular. Bu modeli literatürde yer alan ayrık mikro modelleme yöntemleriyle karşılaştırdılar.

Bu çalıșmada, yığma duvarların mikro model ile analizinde JD4, JD6 ve JD7 Eindhoven duvarlarının [7] 3 boyutlu sabit doğrultulu yayılı çatlak yaklaşımı ile doğrusal olmayan statik itme analizleri yapılmıştır. $\mathrm{Bu}$ duvarlarının deney sonuçlarından elde edilen taban kesme kuvvetitepe yer değiştirme eğrisi ile oluşan çatlak bölgeleri nümerik sonuçlarla karşılaştırılarak yöntemin etkinliği incelenmiștir. Sabit doğrultulu yayılı çatlak modelinde, çatlama oluştuktan sonra kayma gerilmelerinin diğer yüzeye iletimi için "kayma gerilmesi transfer katsayısı" tanımlanmaktadır. $\mathrm{Bu}$ iletim katsayıları açık ve kapalı durumlar için ayrı ayrı 
tanımlanmaktadır. Kapalı iken bu katsayı genelde 0.90 alınmaktadır. Açık iken bu katsayı çatlağın boyuna bağlı olarak değişmektedir. $\mathrm{Bu}$ çalıșmada tuğlanın basınç dayanımının ve kayma gerilmesi iletim katsayısının çözümler üzerine olan etkisi incelenmiştir.

\section{Materyal ve Metot}

$\mathrm{Bu}$ çalışmada, William ve Warnke [12], modelinin özel hali olan üç değișkenli beton modeli kullanılmıştır. Üç değișkenli model William tarafından geliştirilmiş olup, düşük basınç altında çekmeye maruz kesitlerdeki beton için göçme yüzeyini tanımlamaktadır. Zeinkiewicz ve Taylor [13], beton gibi gevrek özelliğe sahip malzemeler için bu malzeme modelinin kullanılabileceğini ortaya koymuşlardır. William Warnke' nin beton göçme yüzeyi modeli yı̆̆ma yapıların geniş çapta modellemesinde etkin bir șekilde kullanılmıștır [14].

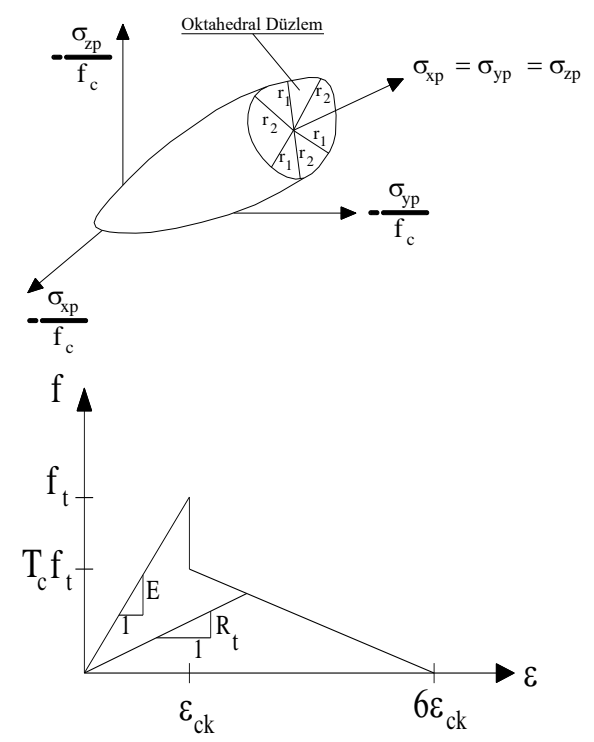

Şekil 1. Üç parametreli model için a) göçme yüzeyi ve b) tek eksenli gerilme-şekil değiștirme bağıntısı [15].

Bu model, Şekil 1.a' da görüldüğü gibi kesiti konveks olan bir koniye yakın görünüme sahiptir. Konveks kesit, simetrik ve düzgün yapıdadır. Burada, $\sigma_{\mathrm{xp}}, \sigma_{\mathrm{yp}}$ ve $\sigma_{\mathrm{zp}}$ birbirlerine dik asal gerilmeleri, $f_{c}$ ise malzemenin tek eksenli basınç dayanımını belirtmektedir. Böyle bir kesit kolayca bir daireye benzetebileceğinden, von
Mises veya Drucker-Prager yaklașımları bu modelin özel bir durumu olarak belirlenebilir [13]. Bu modelde, göçme yüzeyi içerisinde kalan gerilme değerleri elde edildiğinde malzeme lineer elastik davranış göstermektedir. Göçme yüzeyinin dışına çıkılan gerilme değerleri elde edildiğinde ise malzemede çatlama ve ezilmelerin ortaya çıkacağı ifade edilmektedir. Malzemede ortaya çıkan çatlaklar, gerilme yumuşamasını dikkate alıp hesaba katılmaktadır (Şekil 1.b).

\subsection{JD4, JD6 ve JD7 Eindhoven yığma duvarlarının mikro model analizi}

Bu çalışmada, JD4, JD6 ve JD7 Eindhoven yığma duvarlarının mikro modelleme ile doğrusal olmayan statik itme analizleri yapılmıștır. $\mathrm{Bu}$ duvarların boyutları $990 \times 1000 \times 100 \mathrm{~mm}$ olup $210 \times 52 \times 100 \mathrm{~mm}$ ölçülerinde sahip tuğlalar ile harç kalınlığı 10 mm olacak șekilde 16 sıra tuğlaharç kullanılarak inşa edilmiștir. Modelin en üst ve en altında 2 sıra çelik kiriș yer almaktadır. Deneysel çalışmada, ön yükleme olarak üst kirişe düşey bir yayılı yük uygulanmış sonraki yükleme adımında ise aynı kirișe yatay yer değiștirme yükü uygulanarak duvarın taşıma gücü elde edilmiștir. Söz konusu bu ön yükleme durumu 30,120 ve $210 \mathrm{kN}$ olarak uygulanmış ve sırasıyla JD4, JD6 ve JD7 olarak adlandırılmıştır [7].

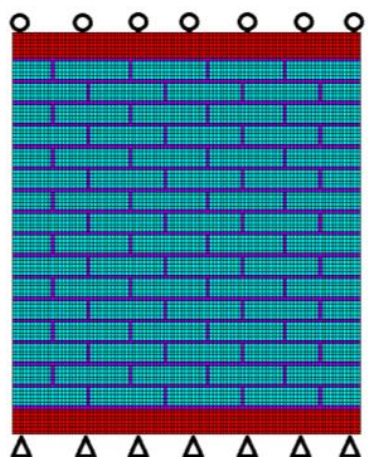

Sekil 2. Eindhoven duvarlarının sonlu elemanlar modeli ve sınır şartları.

Bu modelde harç ve tuğla için ayrı ayrı malzeme özellikleri tanımlanmış olup malzemeler arası bağlantının rijit olduğu kabul edilmiștir. Çözümler için Ansys sonlu eleman paket programı kullanılmıştır [15]. Sayısal modelde 33600 adet dügüm noktası ve 21978 adet üç boyutlu katı sonlu eleman kullanılmıştır. Duvarın tabanındaki çelik kirişlerin alt yüzeyi 
yatay ve düșey doğrultularda tutulu üstteki çelik kirișin üst yüzeyi ise sadece düșey doğrultuda tutulu olacak şekilde sınır şartları uygulanmıștır.

Cözümlerde, duvarın kendi ağırlığı ve üst kirișe uygulanan 30, 120 ve 210 kN' luk düşey yükler ön yükleme aşamasında etki ettirilmiştir. Sonraki yükleme aşamasında ise bu yükler ve yer değiștirme değerleri başlangıç şartları olarak dikkate alınarak çözümler elde edilmiștir. $\mathrm{Bu}$ çalışmada, Eindhoven yığma duvarlarının mikro modelleme ile doğrusal olmayan statik itme analizlerinde; tuğlanın basınç dayanımının ve kayma gerilmesi iletim katsayısı $\beta_{t}$ ' nin çözümler üzerine olan etkisi incelenmiştir.

Tuğla ve harç malzemelerinin elastik ve elastik olmayan malzeme özellikleri Hemant ve ark. [16]' nın önerdiği eşitlikler yardımıyla belirlenmiștir. $\mathrm{Bu}$ araștırmada tuğla malzemesinin elastisite modülü,

$E_{b}=300 f_{b, c} \quad(\mathrm{MPa})$

eşitliği ile hesaplanmaktadır. Burada $f_{b, c}$ tuğlanın tek eksenli basınç dayanımını göstermektedir. Tuğla malzemesinin tek eksenli çekme dayanımı $\left(f_{b, t}\right)$ ise

$$
f_{b, t}=f_{b, c} / 25 \quad(\mathrm{MPa})
$$

denklemi ile hesaplanmaktadır. Aynı zamanda harç malzemesinin elastisite modülü ise,

$E_{m}=200 f_{m, c} \quad(\mathrm{MPa})$

bağıntısı ile hesaplanmaktadır. Burada $f_{m, c}$ harcın tek eksenli basınç dayanımını göstermektedir. Tuğla malzemesinin tek eksenli çekme dayanımı $\left(f_{m, t}\right)$ ise

$$
f_{m, t}=f_{m, c} / 20 \quad(\mathrm{MPa})
$$

eşitliği kullanılarak hesaba katılmaktadır.

\section{Bulgular}

\subsection{Tuğlanın basınç dayanımının çözümler üzerindeki etkisi}

$\mathrm{Bu}$ bölümde JD4, JD6 ve JD7 Eindhoven duvarlarında kullanılan tuğlanın basınç dayanımının yığma duvarın nümerik analizleri üzerindeki etkileri incelenmiștir. Tuğlanın basınç dayanımı için 10-60 $\mathrm{MPa}$ aralığında değişen değerler seçilmiștir [17]. Tuğlanın çekme ve elastisite modülü değerleri ise (1) ve (2) denklemleri yardımıyla hesaplanmıştır. Kayma gerilmesi iletim katsayıları çatlağın açık ve kapalı durumları için sırasıyla 0.05 ve 0.90 olarak dikkate alınmıştır. JD4, JD6 ve JD7 Eindhoven duvarları için (1) ve (2) denklemleri yardımıyla hesaplanan tuğlanın malzeme özellikleri Tablo (1)-(3)' de görülmektedir. Söz konusu bu duvarlarda kullanılan harç malzemesi için harcın basınç dayanımı $10 \mathrm{MPa}$ alınmıştır [14]. Harcın basınç dayanımı yardımıyla Elastisite modülü ve çekme dayanımı için sırasıyla (3) ve (4) denklemleri kullanıldığında $2000 \mathrm{MPa}$ ve $0.5 \mathrm{MPa}$ değerleri elde edilmektedir. Harcın kayma gerilmesi iletim katsayıları ise çatlağın açık ve kapalı durumları için sırasıyla 0.05 ve 0.90 olarak seçilmiştir.

Tablo 1. JD4 Eindhoven duvarları tuğla malzeme özellikleri.

\begin{tabular}{cccccc}
\hline & B1 & B2 & B3 & B4 & B5 \\
\hline $\mathrm{E}_{\mathrm{b}}$ & 9000 & 6000 & 4500 & 3750 & 3000 \\
$\mathrm{f}_{\mathrm{c}, \mathrm{b}}$ & 30.00 & 20.00 & 15.00 & 12.50 & 10.00 \\
$\mathrm{f}_{\mathrm{t}, \mathrm{b}}$ & 1.20 & 0.80 & 0.60 & 0.50 & 0.40 \\
\hline
\end{tabular}

Tablo 2. JD6 Eindhoven duvarları tuğla malzeme özellikleri.

\begin{tabular}{cccccc}
\hline & B1 & B2 & B3 & B4 & B5 \\
\hline $\mathrm{E}_{\mathrm{b}}$ & 15000 & 12000 & 9000 & 6000 & 4500 \\
$\mathrm{f}_{\mathrm{c}, \mathrm{b}}$ & 50.00 & 40.00 & 30.00 & 20.00 & 15.00 \\
$\mathrm{f}_{\mathrm{t}, \mathrm{b}}$ & 2.00 & 1.60 & 1.20 & 0.80 & 0.60 \\
\hline
\end{tabular}

Tablo 3. JD7 Eindhoven duvarları tuğla malzeme özellikleri.

\begin{tabular}{cccccc}
\hline & B1 & B2 & B3 & B4 & B5 \\
\hline $\mathrm{E}_{\mathrm{b}}$ & 18000 & 16500 & 15000 & 12000 & 9000 \\
$\mathrm{f}_{\mathrm{c}, \mathrm{b}}$ & 60.00 & 55.00 & 50.00 & 40.00 & 30.00 \\
$\mathrm{ft}, \mathrm{b}$ & 2.40 & 2.20 & 2.00 & 1.60 & 1.20 \\
\hline
\end{tabular}

JD4 duvarının deney sonuçlarından maksimum taban kesme kuvveti $50.30 \mathrm{kN}$ olarak belirlenmiştir. Nümerik analizlerden hesaplanan taban kesme kuvveti değerleri ise JD4-B1, JD4B2, JD4-B3, JD4-B4 ve JD4-B5 için sırasiyla 72.46, $61.81,51.21,50.21$ ve $41.45 \mathrm{kN}$ olarak elde 
edilmiștir. Maksimum taban kesme kuvvetleri değerleri deney sonuçlarıyla karşılaştırıldığında; JD4-B1, JD4-B2, JD4-B3, JD4-B4 ve JD4-B5 için sirasiyla $\% 44.15, \% 22.95, \% 1.87, \% 0.13$ ve \%17.54 oranlarında farkların oluştuğu belirlenmiștir. $\mathrm{Bu}$ değerler dikkate alındığında en az farkın JD4-B4 için hesaplandığı görülmektedir.

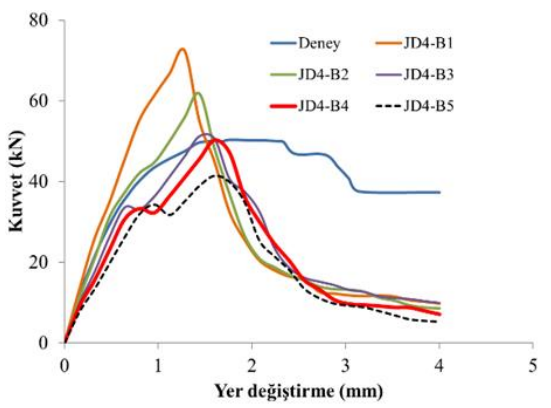

Sekil 3. JD4 Eindhoven duvarının deneysel ve nümerik kuvvet-yer değiștirme grafikleri.

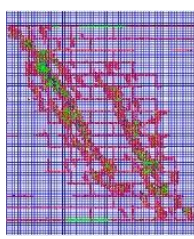

a) JD4-B1

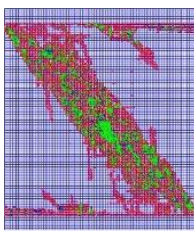

d) JD4-B4

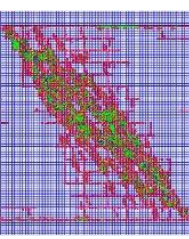

b) JD4-B2

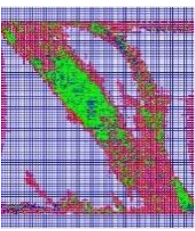

e) JD4-B5

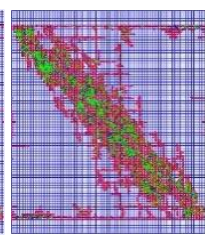

c) JD4-B3

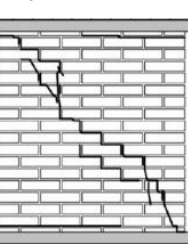

f) Deney
Sekil 4. JD4 Eindhoven duvarının deneysel ve nümerik çatlama grafikleri.

JD4 duvarının deney sonuçlarından maksimum yükün oluştuğu andaki duvarın tepe yer değiştirme değeri ise $1.74 \mathrm{~mm}$ olarak belirlenmiştir. Nümerik analizlerde ise bu yer değiştirme değeri, JD4-B1, JD4-B2, JD4-B3, JD4B4 ve JD4-B5 için sırasıyla 1.28, 1.44, 1.44, 1.60 ve $1.60 \mathrm{~mm}$ olarak elde edilmiştir (Şekil 3). Deneysel sonuçlarıyla karşılaştırıldığında bu yer değiștirme değerleri deney sonuçlarına göre sirasiyla \%26.44, \%17.24, \%17.24, \%8.05 ve \%8.05 oranlarında daha küçük olarak elde edilmiștir. Taban kesme kuvveti ve tepe yer değiștirme değerleri dikkate alındığında her iki büyüklük için en az fark JD4-B4 çözümlerinden elde edilmiștir.

JD4-B1, JD4-B2, JD4-B3, JD4-B4 ve JD4-B5 için tepe yer değiștirme değerlerinin sırasıyla 1.28 , $1.44,1.44,1.60$ ve 1.60 mm' ye ulaștığı anlarda JD4 duvarında oluşan çatlak bölgeleri ve deneyden elde edilen çatlak bölgeleri Şekil 4.' de görülmektedir. Tüm çözümlerde çatlak bölgeleri, JD4 duvarının sağ üst köșesinden başlayıp sola doğru ve sol alt köşesinden başlayıp sağa doğru yatay olarak ilerleyen iki çatlak bölgesi șeklinde elde edilmiştir. İlerleyen yükleme adımlarında sol üst köședen sağ alt köșeye doğru ilerleyen diyagonel bir çatlak bölgesi daha meydana gelmiştir. JD4-B1 çözümünde bu çatlak bölgesi iki parça șeklinde ilerlerken diğer çözümlerde daha geniş bir bölgeye dağınık şekilde elde edilmiștir. Taban kesme kuvveti ve tepe yer değiștirme değerleri için en uygun çözüm olan JD4-B4'ün hasar bölgesi deneyden elde edilen çatlak yörüngesine benzer bölgelerde meydana gelmiş olup çok dağınık bir formda elde edilmiştir.

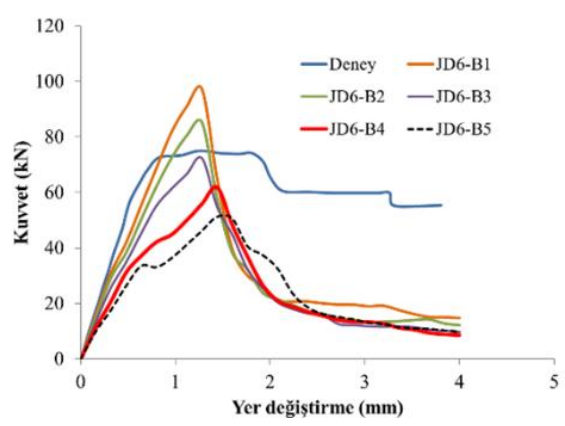

Şekil 5. JD6 Eindhoven duvarının deneysel ve nümerik kuvvet-yer değiștirme grafikleri.

JD6 duvarının deney sonuçlarından maksimum taban kesme kuvveti $74.87 \mathrm{kN}$ olarak belirlenmiștir (Șekil 5). Nümerik analizlerden hesaplanan taban kesme kuvveti değerleri ise JD6-B1, JD6-B2, JD6-B3, JD6-B4 ve JD6-B5 için sırasıyla $97.20,85.18,72.46,61.81$ ve $51.21 \mathrm{kN}$ olarak elde edilmiștir. Maksimum taban kesme kuvveti değerleri deney sonuçlarıyla karşılaştırıldığında; JD6-B1, JD6-B2, JD6-B3, JD6B4 ve JD6-B5 için sırasıyla \%29.82, \%13.76, $\% 3.22, \% 17.45$ ve $\% 31.65$ oranlarında farkların oluştuğu belirlenmiştir. Bu değerler dikkate alındığında en az farkın JD6-B3 için hesaplandığ görülmektedir.

JD6 duvarının deney sonuçlarından maksimum yükün oluştuğu andaki duvarın tepe yer 
değiștirme değeri 1.22 mm olarak belirlenmiștir. Nümerik analizlerde ise bu yer değiștirme değeri JD6-B1, JD6-B2, JD6-B3, JD6-B4 ve JD6-B5 için sirasıyla $1.28,1.28,1.28,1.44$ ve $1.44 \mathrm{~mm}$ olarak elde edilmiştir. Deneysel sonuçlarıyla karşılaştırıldığında bu yer değiştirme değerleri deney sonuçlarına göre sırasıyla $\% 4.92, \% 4.92$, $\% 4.92$, \%18.00 ve \%18.00 oranlarında daha büyük olarak elde edildiği belirlenmiștir. Taban kesme kuvveti ve tepe yer değiştirme değerleri dikkate alındığında her iki büyüklük için en az fark JD6-B3 çözümlerinden elde edilmiştir.

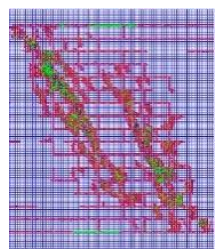

a) JD6-B1

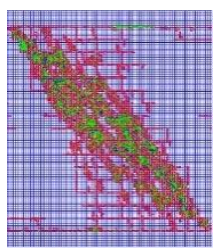

d)JD6-B4

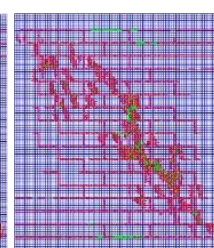

b) JD6-B2

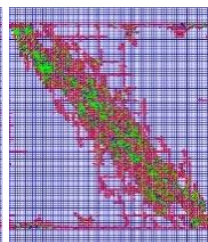

e) JD6-B5

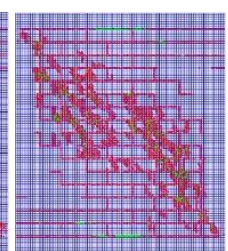

c) JD6-B3

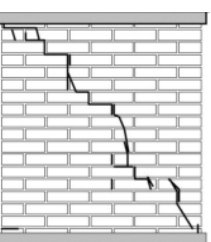

f) Deney
Şekil 6. JD6 Eindhoven duvarının deneysel ve nümerik çatlama grafikleri.

JD6-B1, JD6-B2, JD6-B3, JD6-B4 ve JD6-B5 için tepe yer değiștirme değerlerinin sırasıyla 1.28 , $1.28,1.28,1.44$ ve $1.44 \mathrm{~mm}$ ' ye ulaştığı anlarda JD6 duvarında oluşan çatlak bölgeleri ve deneyden elde edilen çatlak bölgeleri Şekil 6' da görülmektedir. Tüm çözümlerde çatlak bölgeleri JD6 duvarının sağ üst köșesinden bașlayıp sola doğru ve sol alt köșesinden başlayıp sağa doğru yatay olarak ilerleyen iki çatlak bölgesi şeklinde elde edilmiştir. İlerleyen yükleme adımlarında sol üst köședen sağ alt köşeye doğru ilerleyen diyagonel bir çatlak bölgesi daha meydana gelmiştir. JD6-B1 çözümünde bu çatlak bölgesi iki parça şeklinde ilerlerken diğer çözümlerde daha geniş bir bölgede dağınık bir şekilde elde edilmiştir. Taban kesme kuvveti ve tepe yer değiştirme değerleri için en uygun çözüm olan JD6-B3' ün hasar bölgesi deneyden elde edilen çatlak yörüngesine benzer bölgelerde meydana gelmiş olup çok dağınık bir formda elde edilmiştir.
JD7 duvarının deney sonuçlarından maksimum taban kesme kuvveti $100.17 \mathrm{kN}$ olarak belirlenmiştir. Nümerik analizlerden hesaplanan taban kesme kuvveti değerleri ise JD7-B1, JD7B2, JD7-B3, JD7-B4 ve JD7-B5 için sırasıyla 106.41, 99.62, 97.20, 86.87 ve $72.46 \mathrm{kN}$ olarak elde edilmiștir (Şekil 7). Maksimum taban kesme kuvveti değerleri deney sonuçlarıyla karşılaştırıldığında; JD7-B1, JD7-B2, JD7-B3, JD7B4 ve JD7-B5 çözümleri için sırasıyla \%6.22, $\% 0.55, \% 2.97, \% 13.28$ ve $\% 27.66$ oranlarında farkların oluştuğu belirlenmiştir. Bu değerler dikkate alındığında en az farkın JD7-B2 için hesaplandığı görülmektedir.

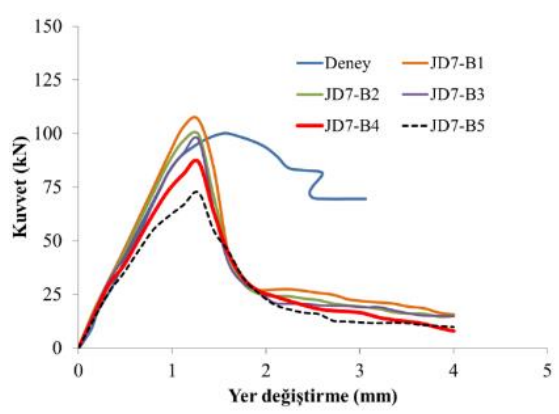

Sekil 7. JD7 Eindhoven duvarının deneysel ve nümerik kuvvet-yer değiştirme grafikleri.

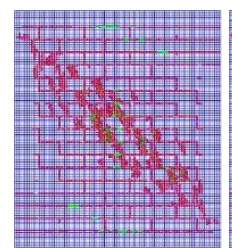

a) JD7-B1

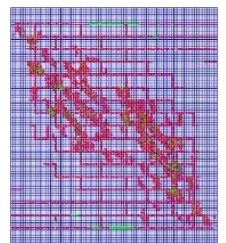

d) JD7-B4

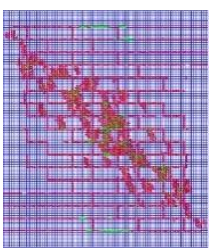

b) JD7-B2

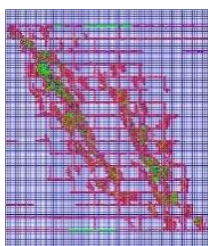

e) JD7-B5

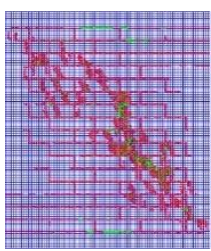

c) JD7-B3
Şekil 8. JD7 Eindhoven duvarının deneysel ve nümerik çatlama grafikleri.

JD7 duvarının deney sonuçlarından maksimum yükün oluştuğu andaki duvarın tepe yer değiștirme değeri ise $1.56 \mathrm{~mm}$ olarak belirlenmiștir. Nümerik analizlerde ise bu yer değiștirme değeri, JD7-B1, JD7-B2, JD7-B3, JD7- 
B4 ve JD7-B5 için tüm çözümlerde aynı değere sahip olup $1.28 \mathrm{~mm}$ olarak hesaplanmıștır. Bu yer değiştirme değeri deney sonuçlarıyla karşılaştırıldığında \%17.95 daha küçük değerler elde edilmiştir. Taban kesme kuvveti ve tepe yer değiştirme değerleri dikkate alındığında JD7 duvarı için en uygun çözümün JD7-B2 olduğu sonucuna ulaşılmıştır. JD7-B1, JD7-B2, JD7-B3, JD7-B4 ve JD7-B5 için tepe yer değiștirme değerinin $1.56 \mathrm{~mm}$ ' ye ulaştığı anlarda JD7 duvarında oluşan çatlak bölgeleri ve deneyden elde edilen çatlak bölgeleri Şekil 8' de görülmektedir. Tüm çözümlerde çatlak bölgeleri JD7 duvarının sağ üst köşesinden başlayıp sola doğru ve sol alt köșesinden bașlayıp sağa doğru yatay olarak ilerleyen iki çatlak bölgesi şeklinde elde edilmiştir. İlerleyen yükleme adımlarında sol üst köşeden sağ alt köşeye doğru ilerleyen diyagonel bir çatlak bölgesi daha meydana gelmiştir. JD7-B1, JD7-B4, JD7-B5 çözümlerinde bu çatlak bölgesi iki parça şeklinde ilerlerken JD7-B2 çözümünde duvar orta bölgesinde dağınık bir formda elde edilmiştir. JD7-B2 çözümünde ise daha dar ve belirgin bir çatlak bölgesi şeklinde elde edilmiştir.

Nümerik analizler sonucunda ön yükleme değeri ile tuğlanın basınç dayanımı arasındaki bir bağıntı elde edilmiş olup Şekil 9' da görülmektedir. Bu eșitlik yığma yapıların mikro model çözümlerinde 3 boyutlu sabit doğrultulu yayılı çatlak modeli kullanıldığı zaman tuğlanın basınç dayanımı ve ön yükleme değerleri arasında bir bağıntıyı içermektedir. Bu eşitlikte korelasyon katsayısı 0.99 olarak elde edilmiştir.

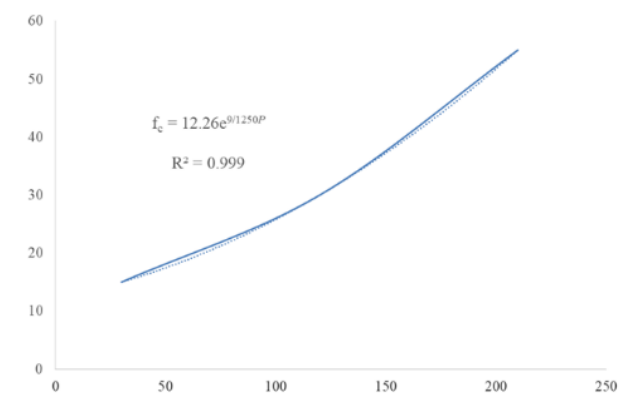

Şekil 9. Ön yükleme değeri-tuğlanın basınç dayanımı arasındaki bağıntı.

JD4, JD6 ve JD7 duvarlarının deney sonuçlarından maksimum yüke ulaştığı andan itibaren sünek bir davranıș sergilediği kuvvetyerdeğiştirme eğrilerinden görülmektedir. $\mathrm{Bu}$ durum duvarın çatlama oluştuktan sonra kayma gerilmesi taşımasından kaynaklanmaktadır [5].
Ancak, nümerik çözümlerde çatlama oluştuktan hemen sonra gevrek bir davranış görülmektedir. $\mathrm{Bu}$ durum modelin kayma gerilmesi açısından incelenmesi gerektiği sonucunu ortaya çıkarmıştır. Bu amaçla, sonraki bölümde nümerik modelde kullanılan kayma dayanım katsayısının çözümler üzerindeki etkisi incelenmiştir.

\subsection{Tuğlanın $\beta_{t}$ katsayısının çözümler üzerindeki etkisi}

$\mathrm{Bu}$ bölümde JD4, JD6 ve JD7 Eindhoven duvarlarının nümerik çözümlerinde, tuğlanın $\beta_{t}$ katsayısının çözümler üzerindeki etkileri incelenmiştir. Nümerik çözümlerde $\beta_{c}, 0.90$ alınmış olup $\beta_{t}$ ise $0.01,0.05,0.1,0.2,0.3$ değerleri seçilerek sonuçlar elde edilmiștir. Çözümler, $\beta_{t}{ }^{\prime} \quad \operatorname{nin} \quad 0.01, \quad 0.05, \quad 0.1, \quad 0.2,0.3$ değerleri olması hallerinde JD4, JD6 ve JD7 duvarları için sırasıya BBT1, BBT2, BBT3, BBT4 ve BBT5 ekleri getirilerek adlandirma yapılmıştır. Harcın kayma gerilmesi iletim katsayıları ise çatlağın açık ve kapalı durumları için sırasıyla 0.05 ve 0.90 olarak seçilmiştir. Çözümlerde kullanılan tuğla ve harç malzemesinin mekanik özellikleri için bölüm 3.1'de elde edilen sonuçlara göre JD4-B4, JD6-B3 ve JD7-B2 çözümlerinde kullanılan malzeme özellikleri seçilmiştir.

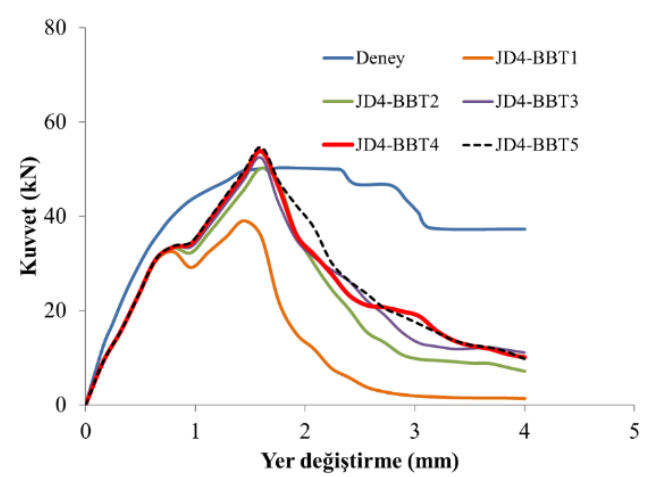

Şekil 10. JD4 Eindhoven duvarının deneysel ve nümerik kuvvet-yer değiștirme grafikleri.

JD4 duvarının deney sonuçlarından maksimum taban kesme kuvveti $50.30 \mathrm{kN}$ olarak belirlenmiştir. Nümerik analizlerden hesaplanan taban kesme kuvveti değerleri ise JD4-BBT1, JD4-BBT2, JD4-BBT3, JD4-BBT4 ve JD4-BBT5 için sırasıyla $39.00,50.21,52.42,53.82$ ve 54.60 
$\mathrm{kN}$ olarak elde edilmiștir (Sekil 10). Maksimum taban kesme kuvveti değerleri deney sonucuyla karşılaştırıldığında; JD4-BBT1, JD4-BBT2, JD4BBT3, JD4-BBT4 ve JD4-BBT5 için sırasıyla $\% 22.41, \% 0.13, \% 4.28, \quad \% 7.07$ ve $\% 8.61$ oranlarında farkların oluștuğu belirlenmiștir. $\mathrm{Bu}$ değerler dikkate alındığında en az farkın JD4-B2 için hesaplandığı görülmektedir.

JD4 duvarının deney sonuçlarından maksimum yükün oluştuğu andaki duvarın tepe yer değiştirme değeri ise $1.74 \mathrm{~mm}$ olarak belirlenmiştir. Nümerik analizlerde ise bu yer değiștirme değeri, JD4-BBT1, JD4-BBT2, JD4BBT3, JD4-BBT4 ve JD4-BBT5 için sırasıyla 1.44, $1.60,1.60,1.60$ ve $1.60 \mathrm{~mm}$ olarak elde edilmiștir. Deney sonucuyla karșılaștırıldığında bu yer değiștirme değerlerinin sırasıyla \%17.24, $\% 8.05, \% 8.05, \% 8.05$ ve $\% 8.05$ oranlarında daha küçük elde edildiği görülmüștür. Taban kesme kuvveti ve tepe yer değiștirme değerleri dikkate alındığında her iki büyüklük için en az fark JD4BBT2 çözümünden elde edilmiştir.

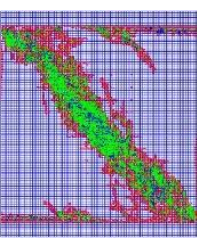

a) JD4-BBT1
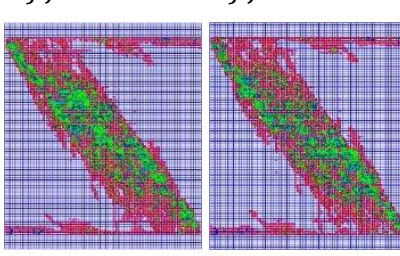

d) JD4-BBT4

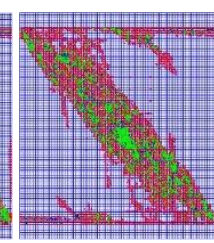

b) JD4-BBT2 c) JD4-BBT3

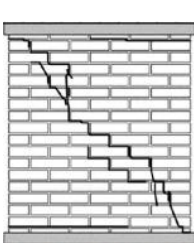

e) JD4-BBT5 f) Deney
Şekil 11. JD4 Eindhoven duvarının deneysel ve nümerik çatlak bölgeleri.

JD4-BBT1, JD4-BBT2, JD4-BBT3, JD4-BBT4 ve JD4-BBT5 için tepe yer değiștirme değerlerinin sirasiyla $1.44,1.60,1.60,1.60$ ve $1.60 \mathrm{~mm}^{\prime}$ ye ulaştığı anlarda JD4 duvarında olușan çatlak bölgeleri ve deneyden elde edilen çatlak bölgeleri Șekil 11' de görülmektedir. Tüm çözümlerde çatlak bölgeleri, JD4 duvarının sağ üst köşesinden başlayıp sola doğru ve sol alt köșesinden bașlayıp sağa doğru yatay olarak ilerleyen iki çatlak bölgesi şeklinde elde edilmiștir. İlerleyen yükleme adımlarında sol üst köședen sağ alt köșeye doğru ilerleyen diyagonel bir çatlak bölgesi daha meydana gelmiștir. Taban kesme kuvveti ve tepe yer değiștirme değerleri için en uygun çözüm olan JD4-BBT2' in hasar bölgesi, deneyden elde edilen çatlak yörüngesine benzer bölgelerde meydana gelmiş olup çok dağınık bir formda hesaplanmıştır.

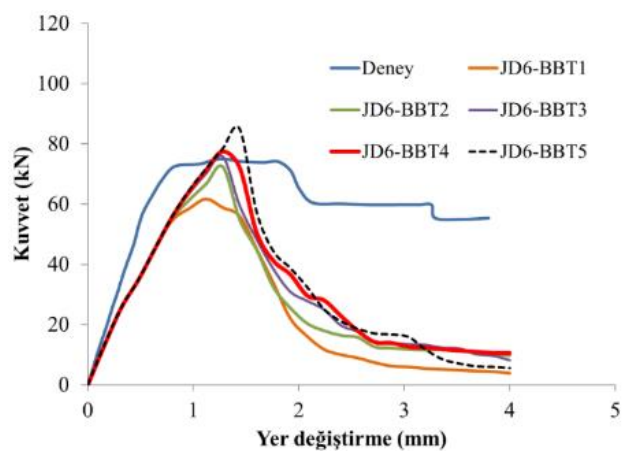

Şekil 12. JD6 Eindhoven duvarının deneysel ve nümerik kuvvet-yer değiștirme grafikleri.

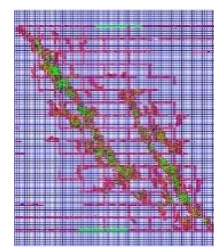

a) JD6-BBT1

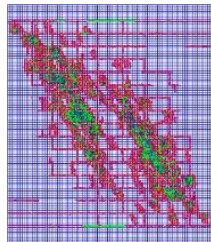

f) JD6-BBT4

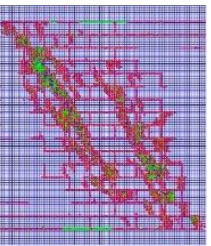

b) JD6-BBT2

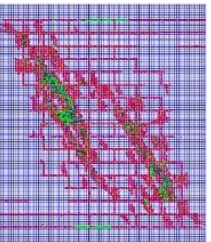

e) JD6-BBT5

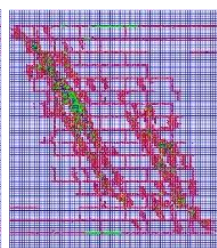

c) JD6-BBT3

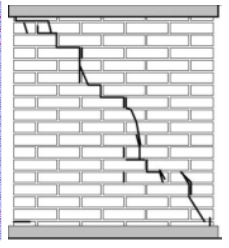

f) Deney
Şekil 13. JD6 Eindhoven duvarının deneysel ve nümerik çatlak bölgeleri.

JD6 duvarının deney sonuçlarından maksimum taban kesme kuvveti $74.87 \quad \mathrm{kN}$ olarak belirlenmiştir. Nümerik analizlerden hesaplanan taban kesme kuvveti değerleri ise JD6-BBT1, JD6-BBT2, JD6-BBT3, JD6-BBT4 ve JD6-BBT5 için sırasıyla $61.23,72.46,75.83,77.58$ ve 85.07 $\mathrm{kN}$ olarak elde edilmiștir (Şekil 12). Maksimum taban kesme kuvveti değerleri deney sonucuyla karşılaştırıldığında; JD6-BBT1, JD6-BBT2, JD6BBT3, JD6-BBT4 ve JD6-BT5 için sırasıyla $\% 17.69$, \%3.22, \%1.28, \%3.61 ve \%13.62 oranlarında farkların oluştuğu görülmüștür. Bu değerler dikkate alındığında en az farkın JD6-B3 çözümlünden hesaplandığı belirlenmiştir. 
JD6 duvarının deney sonuçlarından maksimum yükün oluştuğu andaki duvarın tepe yer değiştirme değeri $1.22 \mathrm{~mm}$ olarak belirlenmiştir. Nümerik analizlerde ise bu yer değiştirme değeri JD6-BBT1, JD6-BBT2, JD6-BBT3, JD6-BBT4 ve JD6-BBT5 için sırasıyla 1.12, 1.28, 1.28, 1.28 ve $1.44 \mathrm{~mm}$ olarak elde edilmiştir. $\mathrm{Bu}$ yer değiștirme değerleri deney sonucuyla karşılaştırıldığında sırasıyla \%8.20, \%4.92, $\% 4.92, \% 4.92$ ve $\% 18.00$ oranlarında farkların oluştuğu görülmüştür. Taban kesme kuvveti ve tepe yer değiștirme değerleri dikkate alındığında her iki büyüklük için en az fark, JD6-BBT3 çözümünden elde edilmiştir.

JD6-BBT1, JD6-BBT2, JD6-BBT3, JD6-BBT4 ve JD6-BBT5 için tepe yer değiștirme değerlerinin sirasiyla $1.28,1.28,1.28,1.12$ ve $1.12 \mathrm{~mm}$ ' ye ulaştığı anlarda JD6 duvarında oluşan çatlak bölgeleri ve deneyden elde edilen çatlak bölgeleri Şekil13' de görülmektedir. Tüm çözümlerde çatlak bölgeleri JD6 duvarının sağ üst köșesinden bașlayıp sola doğru ve sol alt köșesinden başlayıp sağa doğru yatay olarak ilerleyen iki çatlak bölgesi șeklinde elde edilmiştir. İlerleyen yükleme adımlarında, tüm çözümlerde elde edilen bu diyagonel çatlak bölgesi iki parça şeklinde hesaplanmıştır.

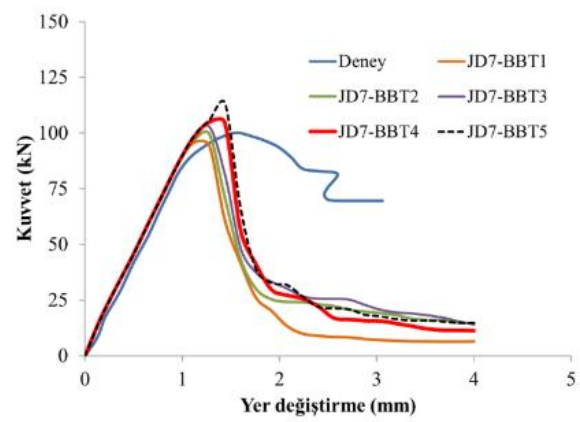

Şekil 14. JD7 Eindhoven duvarının deneysel ve nümerik kuvvet-yer değiștirme grafikleri.

JD7 duvarının deney sonuçlarından maksimum taban kesme kuvveti $100.17 \mathrm{kN}$ olarak belirlenmiștir. Nümerik analizlerden hesaplanan taban kesme kuvveti değerleri ise JD7-BBT1, JD7-BBT2, JD7-BBT3, JD7-BBT4 ve JD7-BBT5 için sırasiyla 95.66, 99.63, 102.76, 105.00 ve $113.63 \mathrm{kN}$ olarak elde edilmiştir (Şekil 14). Maksimum taban kesme kuvveti değerleri deney sonucuyla karşılaștırıldığında; JD7-BBT1, JD7BBT2, JD7-BBT3, JD7-BBT4 ve JD7-BBT5 çözümleri için sırasıyla $\% 4.51, \% 0.55, \% 2.59$, \%4.83 ve \%13.17 oranlarında farkların oluştuğu belirlenmiştir. Bu değerler dikkate alındığında en az farkın JD7-BBT2 için hesaplandığı görülmektedir.

JD7 duvarının deney sonuçlarından maksimum yükün oluştuğu andaki duvarın tepe yer değiștirme değeri ise $1.56 \mathrm{~mm}$ olarak belirlenmiștir. Nümerik analizlerde ise bu yer değiștirme değeri, JD7-BBT1, JD7-BBT2, JD7BBT3, JD7-BBT4 ve JD7-BBT5 için sırasıyla 1.12, $1.28,1.28,1.28$ ve $1.44 \mathrm{~mm}$ olarak hesaplanmıștır. $\mathrm{Bu}$ yer değiștirme değerlerinin deney sonucuna göre $\% 28.21, \% 17.95, \% 17.95$, \%17.95 ve \%7.69 oranlarında daha küçük elde edildiği belirlenmiștir. Taban kesme kuvveti ve tepe yer değiştirme değerleri dikkate alındığında her iki büyüklük için en az fark, JD7-BBT2 çözümünden elde edilmiştir.

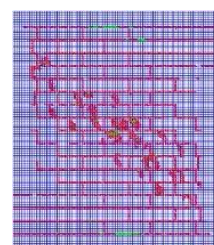

a) JD7-BBT

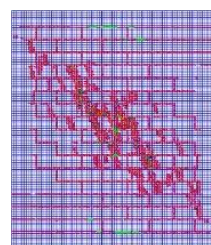

d) JD7-BBT4

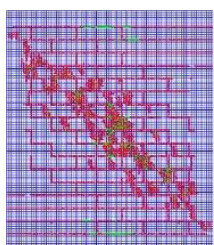

b) JD7-BBT2

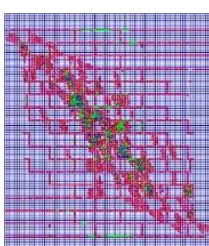

e) JD7-BBT5

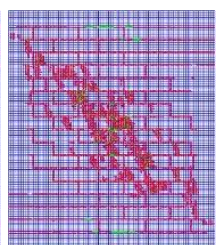

c) JD7-BBT3

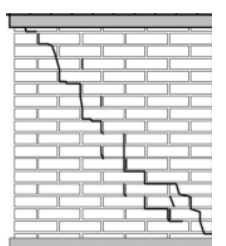

f) Deney
Şekil 15. JD7 Eindhoven duvarının deneysel ve nümerik çatlak bölgeleri.

JD7-BBT1, JD7-BBT2, JD7-BBT3, JD7-BBT4 ve JD7-BBT5 için tepe yer değiștirme değerinin sirasiyla $1.12,1.28,1.28,1.28$ ve $1.44 \mathrm{~mm}$ ' ye ulaştığı anlarda JD7 duvarında oluşan çatlak bölgeleri ve deneyden elde edilen çatlak bölgeleri Şekil 15' de görülmektedir. Tüm çözümlerde çatlak bölgeleri JD7 duvarının sağ üst köșesinden başlayıp sola doğru ve sol alt köşesinden başlayıp sağa doğru yatay olarak ilerleyen iki çatlak bölgesi șeklinde elde edilmiștir. İlerleyen yükleme adımlarında sol üst köşeden sağ alt köșeye doğru ilerleyen diyagonel bir çatlak bölgesi daha meydana gelmiștir.

\section{Tartışma ve Sonuç}

Bu çalıșmada, yığma duvarların mikro seviye modellenmesinde 3 boyutlu sabit doğrultulu yayılı çatlak modelinin yığma duvarların statik 
itme davranıșı üzerindeki etkinliği incelenmiștir. Nümerik analizler için Ansys sonlu eleman programı içerisinde bulunan Solid65 beton elemanı seçilmiştir. Nümerik sonuçların karşılaştırılması amaciyla, JD4, JD6 ve JD7 Eindhoven duvarlarının deney sonuçlarından elde edilen taban kesme kuvveti-tepe yer değiştirme eğrisi ile oluşan çatlak bölgeleri kullanılmıștır.

Sabit doğrultulu yayılı çatlak modelinde, çatlama oluştuktan sonra kayma gerilmelerinin diğer yüzeye iletimi için "kayma gerilmesi transfer katsayısı" tanımlanmaktadır. $\mathrm{Bu}$ iletim katsayıları açık durum için $\beta_{t}$ ve kapalı durum için $\beta_{c}$ olarak adlandırılmaktadır. Kapalı iken bu katsayı genelde 0.90 alınmaktadır. Açık iken bu katsayı çatlağın boyuna bağlı olarak değişmektedir. $\mathrm{Bu}$ çalışmada tuğlanın basınç dayanımının ve $\beta_{t}$ katsayısının çözümler üzerine olan etkisi incelenmiştir. Bu çözümler ışığında elde edilen sonuçlar aşağıda maddeler halinde verilmiştir.

\section{Kaynakça}

[1]. Dilmac, H., Ulutas, H., Tekeli, H., and Demir, F. 2018 The investigation of seismic performance of existing rc buildings with and without infill walls, Computers and Concrete, 22(5), 439-447.

[2]. Kareem, K.M. and Guneyisi, E.M., 2018, "Effect of masonry infill wall configuration and modelling approach on the behaviour of RC frame structures", Arab. J. Sci. Eng., 1-16.

[3]. Karaton M., Aksoy, H.S., Sayın, E. and Calayır, Y, 2017. Nonlinear seismic performance of a 12th century historical masonry bridge under different earthquake levels, Engineerin Failure Analysis, 79, 408-421.

[4]. Chaimoon, K., Attard, M. M., 2007. Modeling of unreinforced masonry walls under shear and compression, Engineering Structures, 29, 20562068.

[5]. Vermeltfoort A Th, Raijmakers T.M.J., Janssen H.J.M., 1993, Shear tests on masonry walls. Proceeding of the 6th North American masonry conference. 1183-93.

[6]. Zucchini, A., Lourenço, P.B., 2009, A micromechanical homogenisation model for masonry: Application to shear walls, International Journal of Solids and Structures, 46, 871-886.

[7]. Vermeltfoort, A.Th., Raijmakers, T.M.J., 1993, Deformation Controlled Tests in Masonry Shear Walls. Part 2 (in dutch), Report TUE/BKO/93.08.

[8]. Adam, J. M., Brencich A., Hughes, T.G. and Tony Jefferson, 2010. Micromodelling of eccentrically loaded brickwork: Study of masonry wallettes, Engineering Structures, 32, 1244-1251.
- Tuğlanın basınç dayanımı üzerine yapılan nümerik analizler sonucunda ön yükleme değeri ile tuğlanın basınç dayanımı arasında $\mathrm{f}_{\mathrm{c}}=12.26 \mathrm{e}^{9 / 1250 P}$ bağıntısı elde edilmiștir. $\mathrm{Bu}$ eşitlik üç boyutlu sabit doğrultulu yayılı çatlak modeli ile yığma duvarların mikro seviye analizlerinde kullanılması amacıyla önerilmiştir.

- Tüm duvarlar için tuğlanın basınç ve çekme gerilmesi için kayma iletim katsayıları sırasıyla 0.90 ve 0.05 seçildiği zaman deney sonucundan elde edilen taban kesme kuvveti, eşik yer değiştirme değerleri ile nümerik çözümler arasında sırasıyla en fazla $\% 3.22$ ve $\% 17.95$ ' lik farklar elde edilmistir.

- Tüm Eindhoven duvarı için ilk hasarlar duvarların sağ üst köșesinden bașlayıp sola doğru ve sol alt köșesinden başlayıp sağa doğru yatay olarak ilerleyen iki çatlak bölgesi şeklinde elde edilmiștir. İlerleyen yükleme adımlarında sol üst köşeden sağ alt köșeye doğru ilerleyen diyagonel bir çatlak bölgesi daha meydana gelmiștir.

[9]. Mohyeddin, A., Goldsworthy, H.M. and Gad, E.F., 2013. FE modelling of RC frames with masonry infill panels under in-plane and out-of-plane loading, Engineering Structures, 51, 73-87.

[10]. Caporale, A., Parisi, F., Asprone, D., Luciano, R. and Prota, A., 2013. Micromechanical analysis of adobe masonry as two-component composite: Influence of bond and loading schemes, Composite Structures, 112, 254-263.

[11]. Petracca, M., Pelà, L., Rossi. R., Zaghi, S., Camata, G. and Spacone, E., 2017. Micro-scale continuous and discrete numerical models for nonlinear analysis of masonry shear walls, Construction and Building Materials, 149, 296-314.

[12]. William K.J., Warnke., 1975. Constitutive model for the tri-axial behaviour of concrete. Proceeding of the International Association for Bridge and Structural Engineering, vol.19, 174.

[13]. Zeinkiewicz, O. C., Taylor, R. L., 1991. Finite Element Method. Vol.2, McGraw-Hill.

[14]. Cavicchi, A., Gambarotta, C., 2005. Collapse Analysis of Masonry Bridges Taking Into Account Arch Fill Interaction. Engineering Structures, 27, 605-615.

[15]. ANSYS. 2015. Finite Element Software. Houston, TX, USA: Swanson Analysis System. Inc.

[16]. Hemant, B. K., Durgesh, C.R., Sudnir K. J., 2007. Stress-Strain Characteristics of Clay Brick Masonry under Uniaxial Compression. Journal of Materials In Civil Engineering, 19, 728-739.

[17]. Xu, C, Xiangli, C., Bin, L., 2012. Modeling of influence of heterogeneity on mechanical performance of unreinforced masonry shear walls, Construction and Building Materials, 26, 90-95. 